\title{
Jakub Szumski
}

Instytut Historii im. Tadeusza Manteuffla Polskiej Akademii Nauk

\section{Międzynarodowy terroryzm w polskiej literaturze i prasie lat siedemdziesiątych XX wieku (wybrane przykłady)}

Zarys treści: Celem artykułu jest analiza wybranych tekstów dotyczących międzynarodowego terroryzmu, opublikowanych w Polsce w latach 1970-1980. Artykuł na przykładach opisów działań terrorystycznych w Europie Zachodniej, USA, na Bliskim Wschodzie oraz w Środkowej i Południowej Ameryce odpowiada na pytanie, co i w jaki sposób pisano o terroryzmie w PRL w tym okresie.

Słowa kluczowe: terroryzm, PRL, prasa, Edward Gierek, RFN, RAF, Frakcja Czerwonej Armii, Czerwone Brygady, Ryszard Kapuściński, Monachium 1972

Keywords: terrorism, Poland, People's Republic of Poland, Polish press, Edward Gierek, RAF, Rote Armee Fraktion, Brigate Rosse, Palestine Liberation Ryszard Kapuściński, Munich 1972

\section{Wstęp}

„Żadne inne zjawisko chyba w ciągu ostatnich lat nie fascynowało w większym stopniu socjologów, psychologów, prawników - a także szeroki ogół” - pisała o terroryzmie w 1979 r. Hanna Hartwig'. Po zamachu na izraelskich sportowców podczas Igrzysk Olimpijskich w Monachium w 1972 r., autorzy „Polityki” zauważali: „Terroryści wywodzą się zarówno spośród włoskich czy austriackich faszystów, jak i z amerykańskich czy francuskich lewaków; po bombę sięga niemiecki anarchista i baskijski nacjonalista; po karabin - urugwajski Tupamaro, irlandzki katolik i chorwacki Ustaszowiec; po zakładników - turecki student, separatysta z Quebeku i palestyński partyzant, a samoloty tak samo porywają japońscy maoiści jak i amerykańskie Czarne Pantery”2.

\footnotetext{
${ }^{1}$ H. Hartwig, Zawód: terrorysta, Warszawa 1979, s. 18.

2 Terrror, „Polityka” 1972, nr 38, s. 1.
} 
W Europie Zachodniej, Stanach Zjednoczonych, na Bliskim Wschodzie i w Ameryce Południowej dochodziło w latach 70. do wielu brutalnych ataków terrorystycznych. Aktywne były grupy reprezentujące różne systemy wartości, dokonujące aktów przemocy w imię radykalnej ideologii, narodowego samookreślenia lub religii. Od końca lat 60 . XX w. terroryzm zaczął mieć charakter międzynarodowy. Aby przeprowadzać akcje, zamachowcy przemieszczali się z kraju do kraju, ich ofiary przestały być bezpośrednio związane ze stawianymi żądaniami, a celem działalności było wzbudzenie strachu, zwrócenie na siebie uwagi i uzyskanie pożądanych zmian w sferze polityki ${ }^{3}$. Polska Rzeczpospolita Ludowa w latach 70. nie była bardzo narażona na ataki terrorystów, a na jej terytorium nie doszło do spektakularnego zamachu dokonanego przez znane na świecie i zorganizowane grupy ${ }^{4}$. Opinia publiczna obserwowała więc rozwój tych zjawisk $\mathrm{z}$ dużą uwagą, lecz z dystansu.

Dramatyczne wydarzenia, takie jak zamachy bombowe, porwania samolotów czy polityczne morderstwa były relacjonowane przez prasę. Zajmowali się tym przede wszystkim zagraniczni korespondenci poszczególnych gazet. Większość mediów, przekazując informacje o atakach politycznej przemocy, posługiwała się depeszami pochodzącymi z Redakcji Zagranicznej Polskiej Agencji Prasowej. Pomimo ścisłej politycznej i administracyjnej kontroli, którym podlegały, krótkie notatki PAP zapewniały wiedzę o podstawowych faktach, liczbie ewentualnych ofiar, syntetycznie ujmowały polityczny i społeczny kontekst ${ }^{5}$.

Dociekliwy czytelnik mógł w latach 70. dotrzeć także do publikacji, które pozwalały poszerzyć zakres informacji o międzynarodowym terroryzmie, poszczególnych grupach i wydarzeniach. Według katalogu komputerowego Biblioteki Narodowej w Warszawie, w latach 1970-1980 w języku polskim ukazało się dziewięć książek poświęconych temu tematowi ${ }^{6}$. Prac takich było w rzeczywistości nieco więcej, gdyż w niektórych przypadkach (konflikt palestyński lub północno-

${ }^{3}$ J. Tyszkiewicz, E. Czapiewski, Historia powszechna - wiek XX, Warszawa 2010, s. 957.

${ }^{4}$ Nie oznacza to jednak, że zagrożenie terrorystyczne nie istniało wcale. W maju 1974 r. w samolocie Polskich Linii Lotniczych „LOT” na warszawskim lotnisku Okęcie w czasie kontroli wykryto ładunek zapalający z mechanizmem zegarowym, który udało się wynieść poza samolot (AIPN, 01208/1248, Sprawa krypt. „Latawiec”). W styczniu 1976 r. pod polski konsulat w Nowym Jorku podłożono bombę, która pomimo wybuchu nie doprowadziła do zniszczenia budynku; P. Pleskot, Real threat or propaganda? „Terrorist attacks” on Polish diplomatic posts in the 70s and the 80s, w: In the Shadow of the Cold War. Domestic and International Terrorism in the Former Communist Countries, ed. T.W. Friis, P. Gasztold-Seń, 2017 (w druku). Inny podobny przypadek z lat 70. opisuje P.M. Majewski, Porwanie Polaków w Iraku w 1976 r. jako przykład „crisis management” w PRL, w: Niepiękny wiek XX, red. B. Brzostek et al., Warszawa 2010, s. 533-543.

${ }_{5}$ R. Piasecka-Strzelec, Wprowadzenie, w: W stużbie propagandy. Polska Agencja Prasowa w latach 1944-1972. Wybór dokumentów i biuletynów, red. R. Piasecka-Strzelec, Kielce 2007, s. 22-27.

${ }^{6}$ Dla porównania, według tego samego źródła, w latach 80. prac takich ukazało się 20, w 90. - 30, a na początku XXI stulecia już 254.

7 A. Bukowska, Palestyńczycy. Ich życie i walka, Warszawa 1978. 
-irlandzki ${ }^{8}$ ) trudno było wyraźnie oddzielić samą polityczną przemoc od szerszych problemów społeczno-politycznych regionu.

W artykule przedstawię prace popularne (książki reporterskie i dziennikarskie, literaturę faktu) oraz naukowe dotyczące terroryzmu i wydawane w latach 70. XX w. Skupię się na - stanowiących większość omawianych tu publikacji beletryzowanych wydawnictwach książkowych. Wydawane w dużych oficynach (Wydawnictwo Harcerskie „Horyzonty”, Wydawnictwo Ministerstwa Obrony Narodowej, Krajowa Agencja Wydawnicza, Młodzieżowa Agencja Wydawnicza, Wydawnictwo Lubelskie) w kilkudziesięciotysięcznych nakładach, stanowiły przystępne źródło wiedzy o wydarzeniach dziejących się na świecie.

Przyjrzę się także, w jaki sposób światowy terroryzm obecny był w publicystyce międzynarodowej dwóch tygodników: „Polityki” i „Kultury”. Wybór tych dwóch tytułów podyktowany został faktem, że znaleźć tam było można najszersze omówienia wydarzeń międzynarodowych. W obu warszawskich redakcjach pracowało wielu utytułowanych dziennikarzy i reporterów, w skali polskiej specjalistów w swoich dziedzinach (aby wymienić tylko autorów pojawiających się w tekście: Jerzy Ambroziewicz, Wojciech Giełżyński, Dominik Horodyński, Ryszard Kapuściński, Adam Krzemiński, Daniel Passent, Maciej Wierzyński) ${ }^{9}$. $\mathrm{Na}$ tematy związane $\mathrm{z}$ terroryzmem publikowano $\mathrm{w}$ latach 70 . także artykuły naukowe - uwzględniłem nieliczne ich przykłady, ukazujące się głównie w wydawanym przez Polski Instytut Spraw Międzynarodowych czasopiśmie „Sprawy Międzynarodowe".

Dodatkowo, Polska Agencja Prasowa wydawała serię Zeszytów Dokumentacyjnych, poświęconych najważniejszym zjawiskom międzynarodowym ${ }^{10}$. Zeszyty te zawierały tłumaczone na język polski oficjalne wypowiedzi polityków, dokumenty oraz fragmenty artykułów z prasy i specjalistycznych czasopism zagranicznych. Zamieszczano teksty pochodzące $z$ gazet o różnym profilu ideowym, nie ograniczając się do prasy komunistycznej. W 1977 r. PAP przygotowała pierwszy zeszyt poświęcony terroryzmowi ${ }^{11}$. W $1978 \mathrm{r}$. ukazał się numer specjalny dotyczący Włoch ${ }^{12}$. Przypadki politycznej przemocy w Republice Federalnej Niemiec doczekały się publikacji w 1977 r. Czytelnik zapoznać się mógł z głosami postaci takiej klasy, jak laureat literackiej Nagrody Nobla Heinrich Böll, historyk Golo Mann czy filozof Herbert Marcuse ${ }^{13}$. Tematyce

\footnotetext{
8 W. Gruszka, Ulster burzy się, Warszawa 1972.

9 U. Jakubowska, Lata 1970-1980, w: Czasopisma społeczno-kulturalne w okresie PRL, red. U. Jakubowska, Warszawa 2012, s. 235-311; T. Mielczarek, Od „Nowej Kultury” do „Polityki”. Tygodniki społeczno-kulturalne i społeczno-polityczne PRL, Kielce 2003.

10 R. Piasecka-Strzelec, op. cit., s. 24.

11 Terroryzm, Warszawa 1977.

12 Terroryzm we Włoszech, Warszawa 1978.

13 Terroryzm $w$ RFN, Warszawa 1977.
} 
niemieckiej oddzielny wybór źródeł poświęcił również Instytut Badania Współczesnych Problemów Kapitalizmu przy KC PZPR ${ }^{14}$. Podobne zbiory artykułów wydawane były także w zachodnich Niemczech ${ }^{15}$. Pokazuje to, że dociekliwy i zainteresowany odbiorca mógł dowiedzieć się o występujących w latach 1970-1980 przypadkach ataków terrorystycznych całkiem niemało.

Na podstawie wyżej wymienionych materiałów chciałbym odpowiedzieć na dwa podstawowe pytania: jak wyglądał stan wiedzy opinii publicznej na temat terroryzmu, którą zdobyć można było z powszechnie dostępnych materiałów? W jaki sposób opisywane i oceniane było samo zjawisko i jego poszczególne postaci i formy? Wybrane przeze mnie źródła książkowe i artykuły prasowe publikowane w tygodnikach umożliwiają odpowiedzi na te pytania, pozwalając odtworzyć szczegółowe opisy konkretnych zdarzeń, na które nie było miejsca w prasie codziennej. Reportaże, publicystyka i literatura naukowa pozwala dodatkowo dotrzeć do komentarzy i ocen.

To, w jaki sposób polskie źródła drukowane relacjonowały i komentowały międzynarodowy terroryzm było częścią PRL-owskiej opowieści o świecie zewnętrznym - zarówno kapitalistycznym, jak i tzw. krajach trzeciego świata. Na opowieść tę wpływ miały czynniki ideologiczne i geopolityczne.

Marksizm-leninizm jako filozofia politycznego działania wypracował jasne, negatywne stanowisko wobec metod jednostkowego terroru. Autorzy pochodzący z bloku wschodniego wielokrotnie podkreślali, że w początkach XX w. Lenin, pozostając $\mathrm{w}$ sporze $\mathrm{z}$ niektórymi towarzyszami walki, sprzeciwiał się aktom terroryzmu wymierzonym $\mathrm{w}$ carat ${ }^{16}$. Odrzucając polityczną przemoc dokonywaną przez zdeterminowane jednostki, krytykowano jej nieskuteczność jako środka mającego doprowadzić do obalenia kapitalizmu ${ }^{17}$. Nie oznaczało to jednakowoż, że kraje komunistyczne na świecie, kierując się względami ideologicznymi, wystrzegały się kontaktów ze światowym terroryzmem i wsparcia dla niego.

Nasilenie się działalności terrorystycznej w latach 70. zbiegło się z okresem otwarcia się Polski na świat. Ofensywa dyplomatyczna Edwarda Gierka pozwoliła ustanowić bliższe niż wcześniej kontakty z krajami zachodnimi, a w przypadku niektórych przywódców - jak kanclerza Republiki Federalnej Niemiec Helmuta Schmidta - umożliwiła osobiste kontakty na najwyższym szczeblu. Polska Rzeczpospolita Ludowa próbowała prezentować się jako przewidywalny i godny zaufania gracz w polityce światowej ${ }^{18}$. Musiało to znaleźć

\footnotetext{
14 Terroryzm w RFN. Przyczyny i skutki. Wybór tekstów, red. W.M. Góralski, Warszawa 1978.

15 Hat sich die Republik verändert? Terrorismus im Spiegel der Presse, Bonn 1978.

16 G. Chaliand, A. Blin, Lenin, Stalin and state terror, w: The History of Terrorism. From Antiquity to Al Qaeda, ed. G. Chaliand, A. Blin, Berkeley-London 2007, s. 197-205.

17 Terrorism and Marxism, „Monthly Review” 1972, no. 6, s. 5.

18 A. Skrzypek, Dyplomatyczne dzieje PRL w latach 1956-1989, Pułtusk-Warszawa 2010, s. 161.
} 
odbicie w stosunku do jednego z największych zagrożeń dla globalnego ładu, jakim w latach 70. był terroryzm. Jednocześnie, pomimo epoki odprężenia, stosunek sił i międzynarodowe sojusze pozostawały bez zmian. Polska była podporządkowana Związkowi Radzieckiemu, a przez to nie mogła pozwolić sobie na samodzielną politykę. Pozostawało umiejętne wpisywanie się w wyznaczane przez ZSRR zadania. To, co ukazywało się $\mathrm{w}$ prasie i popularnych wydawnictwach, zgodne musiało być z założeniami propagandy międzynarodowej Układu Warszawskiego ${ }^{19}$.

Wiedza o tym, jak terroryzm opisywany był w powszechnie dostępnych publikacjach, nie wyczerpuje oczywiście tematu stosunku do niego ze strony ZSRR i państw satelickich. Kraje bloku wschodniego miały skomplikowane relacje $\mathrm{z}$ międzynarodowym terroryzmem. Służby specjalne w sposób tajny wspierały działalność wybranych grup, gwarantując sobie bezpieczeństwo na własnym terytorium oraz czerpiąc z tego rozmaite korzyści. Terroryści i handlarze bronią wykonywali na rzecz służb Układu Warszawskiego zadania wywiadowcze, co pozwalało także na zdobywanie „lewych” środków finansowych. Celem strategicznym była destabilizacja sytuacji politycznej na Zachodzie oraz w tych rejonach świata, w których toczyła się radziecko-amerykańska rywalizacja ${ }^{20}$. Polska Gierka i Jaruzelskiego także uczestniczyła w tego typu współpracy. W Polsce schronienie znajdowali między innymi terroryści z grupy Abu Nidala. Wywiad wojskowy PRL i przedsiębiorstwa zbrojeniowe szeroko współpracowały $\mathrm{z}$ handlarzami bronią i międzynarodowymi terrorystami ${ }^{21}$.

$\mathrm{O}$ obrazie terroryzmu $\mathrm{z}$ lat 70 . w mediach i debatach publicznych najwięcej możemy dowiedzieć się na przykładach: niemieckich sporów wokół terroru Frakcji Czerwonej Armii (RAF) ${ }^{22}$ oraz debat we Włoszech ${ }^{23}$. Dostępne są także

19 T. Leszkowicz, „Polityka prasowa PZPR w latach 1971-1975”, praca magisterska obroniona na Wydziale Dziennikarstwa i Nauk Politycznych UW, mps, Warszawa [wrzesień 2013], s. 109.

20 R.S. Cline, Terrorism. The Soviet Connection, New York 1984.

${ }^{21} \mathrm{~J}$. Bubiło, „Terroryzm po polsku”. Szkice $z$ historii polski $w$ kontekście zjawiska terroryzmu, „Rocznik Wydziału Nauk Prawnych i Ekonomicznych KUL” 6 (2010), z. 1, s. 15; W. Gadowski, P. Wojciechowski, Tragarze śmierci, Warszawa 2015; P. Gasztold-Seń, Between Geopolitics and National Security. Polish Intelligence and International Terrorism during the Cold War, w: Need to Know. Eastern and Western Perspective, ed. W. Bułhak, T.W. Friis, Odense 2014 (Studies in Intelligence and Security), s. 137-162; idem, Międzynarodowi terroryści w PRL - historia niewymuszonej wspótpracy, „Pamięć i Sprawiedliwość” 2013, nr 1, s. 275-315; idem, Biznes z terrorystami. Brudne interesy wywiadu wojskowego PRL $z$ bliskowschodnimi organizacjami terrorystycznymi, „Pamięć i Sprawiedliwość” 2014, nr 1, s. 165-217; idem, Between non-refundable aid and economic profits. Export of arms from the Polish People's Republic's to the third world countries, w: Post-1945 Poland: Modernities, Transformations and Evolving Identities. Working papers. Programme of Modern Poland/2016, Oxford 2016, https://production.sant.ox.ac.uk/ sites/default/files/related-documents/post-1945_poland_working_papers_pomp_2016.pdf (dostęp: 25 V 2016).

${ }^{22}$ Wybrane przykłady: H. Balz, Von Terroristen, Sympathisanten und dem starken Staat. Die öffentli- 
publikacje poświęcone postrzeganiu terroryzmu nie tylko z punktu widzenia pojedynczego, dotkniętego tym problemem kraju. Niestety, jak zauważył Jacco Pekelder, pod postacią historii „międzynarodowej” lub „transnarodowej” czytelnik otrzymuje zazwyczaj perspektywę ograniczoną tylko do dwóch-trzech krajów Europy Zachodniej, nie wspominając już o uwzględnieniu doświadczenia wschodnioeuropejskiego ${ }^{24}$.

Petra Terhoeven, opierając się głównie na wypowiedziach intelektualistów, wpływowych osobistości, polityków i działaczy społecznych, opisała, w jaki sposób dramatyczne wydarzenia „Niemieckiej Jesieni” 1977 r. wpływały na wzajemne postrzeganie się parlamentarnych i pozaparlamentarnych sił politycznych w RFN, Włoszech i Francji ${ }^{25}$. W 2008 r. ukazał się tom zbiorowy poświęcony holenderskim reakcjom politycznym i prasowym na terror $\mathrm{RAF}^{26}$. Obecność międzynarodowego terroryzmu w literaturze i prasie krajów bloku wschodniego można więc określić jako zupełnie nieopisaną. Paradoksalnie, więcej wiadomo na temat kontaktów służb specjalnych bloku wschodniego z organizacjami terrorystycznymi, niż na temat ich obrazu w debacie publicznej, co przez większą dostępność źródeł wydawało by się zadaniem łatwiejszym.

\section{Zagadnienia ogólne}

Terroryzm to - według ogólnie przyjętej definicji - przemoc stosowana z zamiarem realizacji określonych i skalkulowanych celów politycznych ${ }^{27}$. Większość prac, które poddałem analizie, miała charakter przyczynkarski i opisowy, nie skupiała się więc na teoretycznej i terminologicznej precyzji. Andrzej Bernard określał

che Debatte über die RAF in den 70er Jahren, Frankfurt-New York 2008; A. Musolff, Terrorismus im öffentlichen Diskurs der BRD. Seine Deutung als Kriegsgeschehen und die Folgen, H. Balz, Der „Sympathisanten” - Diskurs im Deutschen Herbst, M. Steinseifer, Terrorismus als Medienereignis im Herbst 1977. Strategien, Dynamiken, Darstellungen, Deutungen, w: Terrorismus in der Bundesrepublik. Medien, Staat und Subkulturen in den 1970er Jahren, hrsg. H-G. Haupt, J. Requate, K. Wienhauer, Frankfurt-New York 2008, s. 302-382.

23 A. Locher, Bleierne Jahre. Linksterrorismus in medialen Aushandlungsprozessen in Italien 1970-1982, Zürich 2013.

${ }^{24}$ J. Pekelder, Book review: Petra Terhoeven, Deutscher Herbst in Europa. Der Linksterrorismus der Siebziger Jahre als transnationales Phänomen, München 2014, „International Review of Social History" 60 (2015), no. 2, s. 300-302.

25 P. Terhoeven, Deutscher Herbst in Europa. Der Linksterrorismus der Siebziger Jahre als transnationales Phänomen, München 2014, s. 19-24.

${ }^{26}$ J. Pekelder, Herbst in Holland. Die RAF in den Niederlanden 1970-1980, J. Martens, „Polizei und Justiy drehen völlig durch". Die Rotee Armee Fraktion in den niederländischen Medien, w: Der "Deutsche Herbst" und die RAF in Politik, Medien und Kunst. Nationale und internationale Perspektiven, hrsg. N. Colin, B. de Graaf, J. Pekelder, J. Umlauf, Bielefeld 2008, s. 17-36, 91-109.

27 The Terrorism Reader, ed. D.J. Whittaker, London 2003, s. 3-13. 
terroryzm jako „przemoc i zastraszanie stosowane przez obiektywnie słabszych wobec silniejszych”, dodając także, że jego podstawą była „manipulacja strachem”28.

Kontrowersyjna była nie tyle sama definicja terroryzmu, ile raczej problem oddzielenia go od usprawiedliwionej walki narodowowyzwoleńczej. Na tym tle toczyły się na forum międzynarodowym ożywione debaty, na co w 1976 r. wskazywała Barbara Kwiatkowska-Czechowska ${ }^{29}$. Przywołany już Bernard zauważał, że „wszelka dyskusja, a tym bardziej ocena terroryzmu jest przejawem walki ideologiczno-politycznej”. „Prasowe informacje na temat terroryzmu - kontynuował - są zniekształcone, a to z tej prostej przyczyny, że światowy system informacji jest w olbrzymiej większości w rękach klas posiadaczy, prawicy, elity władzy. Pod polityczny i propagandowy mikroskop bierze się sam akt gwałtu, odrywając go od tła społeczno-politycznego"30.

Użycie politycznej przemocy nazywane było terroryzmem i oceniane negatywnie w przypadkach, w których istniała możliwość legalnej walki politycznej w ramach systemu demokratycznego. Odpowiednią klasyfikację przedstawił w 1979 r. Longin Tadeusz Szmidt. Akty terroru podzielił ze względu na rodzaj porządku politycznego, który występował w kraju ich dokonania. Do pierwszej kategorii zaliczył kraje z rozwiniętym systemem legalnej walki politycznej (Wielka Brytania, Francja, Republika Federalna Niemiec, Belgia, Austria, Włochy, USA, Japonia). Do drugiej - kraje, w których formy owej walki były opóźnione (Grecja, Hiszpania, Portugalia, Irlandia). W końcu - kraje, gdzie legalnych form walki politycznej nie było (kraje Ameryki Południowej i Środkowej, Afryka, Azja) ${ }^{31}$. Według autora użycie przemocy w pierwszej kategorii państw powinno być uważane za terroryzm, gdyż równocześnie dostępne były inne kanały osiągania celów politycznych. Polityczna przemoc mogła (lecz nie musiała) być uzasadniona w drugim i trzecim przypadku. Jak się okaże, sposób myślenia Szmidta zastosować można było do większości analiz powstałych w latach 70 .

Polscy autorzy posługiwali się także pojęciem „terroryzmu państwowego”, czyli działań, które podejmowane były przez władze poszczególnych państw przeciwko własnym obywatelom lub interesom innego kraju, za pomocą metod niezgodnych z prawem międzynarodowym. W wydanym w 1974 r. Piractwie XX wieku Zbigniew Domarańczyk opisywał różne przypadki ataków na morzu i w powietrzu. Przykładowo, misja zestrzelonego nad Związkiem Radzieckim w 1960 r. samolotu szpiegowskiego U-2 określona została mianem „powietrznego

28 A. Bernard, Strategia terroryzmu, Warszawa 1978, s. 22, 33.

29 B. Kwiatkowska-Czechowska, Zagadnienie terroryzmu w świetle prawa międzynarodowego, „Sprawy Międzynarodowe” 1976, nr 11, s. 82-96; także: J. Latkiewicz, J. Skoczylas, Problematyka terroryzmu międzynarodowego w pracach ONZ, „Zeszyty Naukowe ASW” 9 (1975).

30 A. Bernard, op. cit., s. 217, 218.

31 L.T. Szmidt, Terroryzm a państwo. Studium poświęcone historycznym, socjologicznym i agonologicznym aspektom terroryzmu, Lubin 1979, s. 20-21, 319-321. 
piractwa”, a stojący za nią prezydent Dwight Eisenhower - wprost „politycznym piratem". Stąd byl już tylko o krok od terroryzmu. W posiadającym teoretyczne ambicje zakończeniu książki Domarańczyka inny reporter, Longin Zaręba, właściwie nie różnicował już państwowego piractwa i terroryzmu, a pojęcia te wiązał wyłącznie z amerykańską polityką w Azji, Ameryce Środkowej i Południowej oraz izraelskimi poczynaniami na Bliskim Wschodzie ${ }^{32}$.

Zbigniew Domarańczyk ideę tę rozwinął w książce z 1979 r. Terroryzm, w której terroryzmem państwowym nazywał amerykańskie działania w Wietnamie, izraelskie na zachodnim brzegu Jordanu, a odwołując się do odleglejszych przykładów historycznych - niemiecką okupację Europy. O Izraelu pisał jako „państw[ie], które w swojej polityce nie waha się łamać podstawowych zasad prawa międzynarodowego, nie stroni również od metod czysto terrorystycznych"33. Państwowym terrorem miały być także podejmowane przez funkcjonariuszy Centralnej Agencji Wywiadowczej (CIA) próby zamachu na życie Fidela Castro czy organizowane przez chilijskie służby Augusta Pinocheta morderstwa podejrzanych o terroryzm działaczy lewicowych ${ }^{34}$.

Klasyczną krytykę indywidualnego terroru z punktu widzenia marksizmu-leninizmu przedstawił w Strategii terroryzmu przywołany tu już Andrzej Bernard. Pisał on, iż metody i ideologie terrorystyczne nie mogą być uznane za skuteczny sposób walki rewolucyjnej i obalenia światowego kapitalizmu, gdyż pomijają ekonomiczne prawa historii oraz zakładają, że pojedynczy akt przemocy dokonany przez zdeterminowaną jednostkę doprowadzić może do zmiany dziejowej. Autor tego typu poglądy określił mianem „wypaczenia” idei lewico$w_{y y c h}{ }^{35}$. Podobnie twierdził Zbigniew Domarańczyk. „Marksizm reprezentuje pogląd, że obalenie społeczeństwa kapitalistycznego i ustanowienie socjalistycznego może dokonać się jedynie na drodze walki klasowej - pisał w 1979 r. Doświadczenie wykazuje, że indywidualny terror nie wywiera korzystnego efektu w tej dziedzinie" 36 .

Ideologiczną obcość lewicowych ruchów radykalnych na Zachodzie wobec klasycznego marksizmu podkreślał w 1979 r. Jerzy Muszyński. W pracy Utopiści i desperaci - wspótczesna ultralewica, prezentował - zgodnie z własną klasyfikacją - ideologię ruchów anarchistycznych, neotrockistowskich, maoistowskich oraz filozofię „nowej lewicy” i stwierdzał, że w odróżnieniu od marksizmu-leninizmu

\footnotetext{
32 Z. Domarańczyk, Piractwo XX wieku, Warszawa 1974, s. 7-49, 76-88, 281-295.

33 Idem, Terroryzm, Warszawa 1979, s. 44.

${ }^{34}$ Ibidem, s. 44, 118-134. Wydarzeniom w Chile poświęcony był także artykuł działacza komunistycznego L. Inostroza, Interwencja i kontrrewolucja w Chile, „Sprawy Międzynarodowe” 1975, nr 4, s. 62-74; J. Dinges, Czas Kondora. Jak Pinochet i jego sojusznicy zasiali terroryzm na trzech kontynentach, przeł. T. Fiedorek, Warszawa 2015.

35 A. Bernard, op. cit., s. 7.

36 Z. Domarańczyk, Terroryzm..., s. 95.
} 
tego typu sposoby myślenia nie mają zakorzenienia w realnych problemach społecznych i gospodarczych oraz są specyficznym produktem społeczeństw zachodnich i rozpolitykowania młodzieży. Ta bowiem, buntując się zarówno przeciwko kapitalizmowi, jak i radzieckiemu komunizmowi, przestawała rozumieć rzeczywiste problemy współczesnego świata ${ }^{37}$. Lekarstwem na ideologiczne choroby miało być podporządkowanie się kontrolowanym przez Moskwę partiom komunistycznym. Prezentowane były one jako przestrzeń umożliwiająca prowadzenie „postępowej” i rewolucyjnej działalności w sposób bezpieczny, bez uciekania się do przemocy i staczania się w „lewacką” ideologię ${ }^{38}$. Podobną rekomendację kierowali ku lewicowym radykałom dziennikarze „Polityki” w przeglądowym, dedykowanym terroryzmowi numerze tygodnika ${ }^{39}$.

Za podstawowe przyczyny terroryzmu uznawano kapitalizm i kolonializm. Te dwa wątki przebijają praktycznie w każdym tekście dotyczącym politycznej przemocy. Jerzy Bukowski dowodził, że to sam system gospodarki rynkowej powoduje zbrojny opór przeciwko państwu, a miejskie partyzantki powstają nawet w najbogatszych krajach świata, czego dowodem miała być kalifornijska Symbioniczna Armia Wyzwolenia (SLA), wsławiona w 1974 r. porwaniem dziedziczki medialnej fortuny Patricii (Patty) Hearst ${ }^{40}$. Kolonializm amerykański i izraelski był przyczyną wybuchów przemocy w Ameryce Południowej i na Bliskim Wschodzie, holenderski - zbrojnych wystąpień dyskryminowanych Molukańczyków napadających na pociągi. Żadnych wątpliwości nie pozostawiał w tym zakresie Longin Tadeusz Szmidt, autor najbardziej naukowej z przywoływanych tu prac - wydanej w 1979 r. książki Terroryzm a państwo. Terroryzm był „immanentnie związan[y] z istnieniem antagonizmów klasowych w ustroju kapitalistycznym, co w krajach zachodnich skwapliwie się zamazuje" 41 .

Wątek nierozerwalnego związku kapitalizmu z terroryzmem (i szerzej, nasilaniem się przemocy) rozwijał Andrzej Bernard. Autor ten twierdził, że jedną z przyczyn terroryzmu było wychowanie i socjalizacja młodzieży w zachodnich społeczeństwach. Od najmłodszych lat wystawione na kontakt $\mathrm{z}$ agresją i przemocą w radiu i telewizji amerykańskie nastolatki same wykazywały do nich większą skłonność. Świadczyć o tym miały wyższe wskaźniki przestępczości w krajach kapitalistycznych. Za jednym z zaniepokojonych dziennikarzy amerykańskich Bernard opisywał to następująco: „ «Typowe» obrazki z życia Amerykanów, pokazywane w telewizji, to przerywanie ciąży, stosunki pozamałżeńskie, malwersacje, szantaże, morderstwa, narkotyki, podsłuch telefoniczny" ${ }^{42}$.

\footnotetext{
37 J. Muszyński, Utopiści i desperaci - wspótczesna ultralewica, Warszawa 1979, s. 7-8.

38 J. Marciniak, Uwaga, komunikat nadzwyczajny, Warszawa 1976, s. 154.

39 Terrror, „Polityka” 1972, nr 38, s. 1, 3, 4-5.

40 J. Bukowski, Patty czy Tania? Historia Patrycji Hearst, Warszawa 1977, s. 38.

${ }^{41}$ L.T. Szmidt, op. cit., s. 5.

42 A. Bernard, op. cit., s. 41.
} 
Wybuchom przemocy sprzyjała ponadto bieda i brak nadziei oraz przekonanie, że jednostki mogą zmieniać historię - co dla ortodoksyjnego marksisty brzmiało jak herezja. W systemach przedstawicielskich i demokratycznych terroryści mieli mniejsze możliwości oddziaływania na państwo, a właściwie tylko w jednoosobowych dyktaturach można - przekonywał Szmidt - pojedynczym aktem terroru (np. zamachem na dyktatora) dokonać znaczącej zmiany politycznej ${ }^{43}$.

$\mathrm{Z}$ tego typu analiz wynikało, że $\mathrm{w}$ rozwiniętej formie terroryzm nie mógł wystąpić w krajach bloku wschodniego, w których nieznane były napięcia społeczne krajów zachodnich i postkolonialnych. „System socjalistyczny nie tworzy pożywki dla politycznego terroryzmu, który jest $\mathrm{w}$ efekcie także pewną formą reakcji na społeczną krzywdę i niesprawiedliwość - dowodził Andrzej Bernard. Nieliczne akty zbliżone do terroryzmu mają tu charakter jednoznacznie przestępczy i kryminalny" ${ }^{44}$. Longin Tadeusz Szmidt twierdził nawet, że wraz z upadkiem kapitalizmu zniknie też terroryzm ${ }^{45}$.

Problematyka światowego terroryzmu uwikłana była w konfrontację zimnowojenną oraz $\mathrm{w}$ skomplikowaną sieć geopolitycznych powiązań PRL-u w „trzecim świecie". Tematem tabu były relacje światowego terroryzmu ze służbami specjalnymi krajów bloku wschodniego. Terroryzm nie był analizowany jako problem w relacjach Wschód-Zachód. Większość opisów sugerowała, iż był on wyłączną odpowiedzialnością świata zachodniego. Związek Radziecki nie był pierwszoplanowym bohaterem polskich opowieści o światowym terroryzmie. Pojawiał się w analizach niezwykle rzadko, na przykład jako rozjemca na Bliskim Wschodzie czy prawdziwy przyjaciel i adwokat narodów arabskich ${ }^{46}$. Adam Krzemiński w artykule z 1972 r. stanowczo odpierał zarzuty, jakoby niemiecka Frakcja Czerwonej Armii była wspomagana przez tajne służby Związku Radzieckiego i innych krajów bloku ${ }^{47}$. „Na specjalną prośbę Senatu Berlina Zachodniego do akcji włącza się także służba graniczna Niemieckiej Republiki Demokratycznej. $\mathrm{Na}$ całej granicy wzmocniono posterunki i zaostrzono kontrolę na przejściach" opisywał współpracę na linii Bonn-Berlin podczas obławy na porywaczy polityka CDU Petera Lorenza w 1975 r. Zbigniew Domarańczyk ${ }^{48}$.

Jeżeli krytykowano metody stosowane przez terrorystów, a całe zjawisko uważano za zagrażające ładowi międzynarodowemu, konsekwencja wymagałaby podobnego traktowania rządów krajów, które ten terroryzm finansowały i wspierały. Problem w tym, że o ile służby specjalne krajów satelickich ZSRR swoje działania prowadziły w sposób tajny, o tyle sojusznicy Związku Radzieckiego

\footnotetext{
43 L.T. Szmidt, op. cit., s. 5.

44 A. Bernard, op. cit., s. 221.

45 L.T. Szmidt, op. cit., s. 45.

${ }^{46}$ J. Marciniak, op. cit., s. 95.

47 A. Krzemiński, Wojna sześciu, „Polityka” 1972, s. 9.

48 Z. Domarańczyk, Terroryzm..., s. 233.
} 
w krajach arabskich i w Północnej Afryce pomocy terrorystom udzielali zupełnie jawnie. Nie można było jeszcze mówić o zorganizowanym systemie państwowego wspierania terroryzmu, lecz w wielu przypadkach pomoc ta widoczna była gołym okiem ${ }^{49}$.

Od 1972 r. klientem Związku Radzieckiego był krwawy dyktator Ugandy Idi Amin. W lipcu 1976 r. znalazł się na czołówkach światowych gazet, gdy na lotnisku w Entebbe przyjął porwany z Tel Awiwu samolot Air France, na którego pokładzie znajdowało się wielu obywateli izraelskich. Zachodnioniemiecko-palestyński oddział terrorystów zażądał uwolnienia przetrzymywanych $\mathrm{w}$ więzieniach na całym świecie towarzyszy walki oraz sowitego okupu. W brawurowej akcji służby specjalne Izraela, przy relatywnie małych stratach, odbiły zakładników, zabijając przy okazji wielu ugandyjskich żołnierzy i doszczętnie niszcząc najważniejsze lotnisko w kraju wraz ze stacjonującymi tam radzieckimi migami ${ }^{50}$.

Opisując ten incydent, Andrzej Bernard w jednym miejscu cytował amerykańskiego dziennikarza, wskazując na nieprzewidywalność ugandyjskiego prezydenta i niejasne motywacje stojące za zgodą na lądowanie porwanej maszyny. Potem już od siebie dodawał, że to właśnie dzięki inicjatywie Amina udało się uwolnić zakładników ${ }^{51}$. W relacji z operacji Entebbe Hanna Hartwig także nie wspominała o niejasnej roli Amina w całej historii ${ }^{52}$.

Drobiazgowo opisując losy zachodnioniemieckiej Frakcji Czerwonej Armii, Bernard taktownie nie wspominał, iż po ucieczce z RFN w 1970 r. jej członkowie szkolili się w palestyńskim obozie Al-Fatah w Jordanii. Nie miał jednak oporów, aby opisać, jak mudżahedini z Libanu gościli terrorystów z Japońskiej Armii Czerwonej ${ }^{53}$. „Baader wraz ze swoim sztabem, oczywiście wszyscy z fałszywymi paszportami, odbędzie podróż za granicę, starając się nawiązać kontakty z terrorystami z innych państw - pisał Zbigniew Domarańczyk. - Nie bardzo mu się to udaje" ${ }^{\text {"4 }}$. Czytelnik z jego książki nie dowiedział się, gdzie konkretnie niemiecki terrorysta próbował nawiązywać kontakty. O jordańskim szkoleniu członków RAF bez ogródek pisali natomiast autorzy „Polityki” ${ }^{2}$.

Chcąc w latach 70. pisać o międzynarodowym terroryzmie, nie dało się ukryć, że państwa, które wraz ze Związkiem Radzieckim tworzyły antyizraelski i antyamerykański front, były jednocześnie bezpieczną przystanią dla członków grup

\footnotetext{
49 J. Tyszkiewicz, E. Czapiewski, op. cit., s. 959.

50 Transnational Terrorism. A Chronology of Events, 1968-1979, ed. E.F. Mickolous, London 1980, s. 621-625.

51 A. Bernard, op. cit., s. 13, 178.

52 H. Hartwig, op. cit., s. 77.

53 A. Bernard, op. cit., s. 101.

54 Z. Domarańczyk, Terroryzm..., s. 230.

55 Terrror, „Polityka” 1972, nr 38, s. 1,3, 4-5.
} 
terrorystycznych. Autorzy reporterskiej książki dotyczącej RAF cytowali jej lidera Andreasa Baadera, który podczas jednego z przesłuchań przedstawiał listę krajów gotowych ewentualnie przyjąć go $\mathrm{z}$ otwartymi ramionami. Były to: Wietnam, Algieria, Libia, Południowy Jemen, Irak. Jego towarzysz broni Jan-Karl Raspe dodawał do tego jeszcze Angolę, Etiopię, Mozambik, Gwineę-Bissau oraz Soma$\operatorname{lię}^{56}$. Zaznaczając, że źródłem był raport przygotowany przez Pakt Północnoatlantycki, Bernard przedstawił listę krajów wspierających i finansujących światowy terroryzm. Znalazły się na niej: Irak, Syria, Libia oraz Południowy Jemen - kraje będące radzieckimi, a więc i polskimi sojusznikami politycznymi i handlowymi, w tym szczególnie PRL-owskich central zbrojeniowych ${ }^{57}$.

\section{Zachód}

Terroryści z Frakcji Czerwonej Armii (Rote Armee Fraktion, RAF) w latach 70. wstrząsnęli zachodnimi Niemcami. Rozpoczęta w 1970 r. fala przemocy obejmowała napady na banki, zamachy bombowe, porwania i morderstwa z pobudek politycznych i ideologicznych ${ }^{58}$. Eskalacji nie zatrzymało nawet dokonane w 1972 r. aresztowanie założycieli organizacji: Andreasa Baadera, Ulriki Meinhof i Gudrun Ennslin. W najbardziej dramatycznym roku 1977, znanym w niemieckiej pamięci historycznej jako „Niemiecka jesien”, zachodnioniemieccy terroryści, aby zdestabilizować kraj i doprowadzić do uwolnienia przebywających w więzieniu liderów ugrupowania, 5 września uprowadzili w Kolonii Hannsa Martina Schleyera, prezydenta Niemieckiego Związku Pracodawców. W następnym tygodniu, 13 października, czterech Palestyńczyków sterroryzowało załogę lecącego z Majorki do Frankfurtu samolotu Lufthansy „Landshut”, i po długiej podróży wylądowało maszyną w Mogadiszu w Somalii. Ich żądania były podobne - uwolnienie przebywających $\mathrm{w}$ więzieniu założycieli RAF i umożliwienie im bezpiecznego wyjazdu z Niemiec. 18 października zachodnioniemiecka antyterrorystyczna jednostka GSG 9 doprowadziła do szczęśliwego uwolnienia przetrzymywanych w samolocie zakładników. Na wieść o tym przebywający w więzieniu założyciele RAF popełnili zbiorowe samobójstwo. 19 października koło Miluzy we Francji znaleziono ciało Schleyera, którego porywacze zamordowali krótko po tym, jak wiadomość o udanej akcji w Mogadiszu dotarła do Europy ${ }^{59}$. Pomimo śmierci Baadera, Meinhof i Ensslin kolejne generacje Frakcji Czerwonej Armii organizowały ataki bombowe jeszcze do początku lat 90 .

\footnotetext{
56 J. Moszczeński, M. Wągrowska, 50 dni grozy, Warszawa 1978, s. 50, 55, 59.

57 A. Bernard, op. cit., s. 152.

58 The Terrorism Reader..., s. 27-28, 195-213; J. Angster, Die Bundesrepublik 1963-1982. Reform und Krise, Darmstadt 2012, s. 102-107.

59 Transnational Terrorism..., s. 721-724.
} 
Początkowo zjawisko skrajnie lewicowego terroryzmu w Niemczech było w PRL raczej lekceważone. W artykule z 1972 r. Adam Krzemiński, pomimo ofiar liczonych już w dziesiątkach, nazwał działalność ruchu „polityczną anegdotą” i zapowiadał, że wraz z aresztowaniem Ulriki Meinof i Anderasa Baadera działalność terrorystyczna w RFN się zatrzyma ${ }^{60}$. Podobne nadzieje wyrażał dziennikarz „Kultury” Edward Dylawerski ${ }^{61}$.

Gdy tak się nie stało, polscy dziennikarze zaczęli nadrabiać zaległości i prezentowali szerokie polityczno-społeczne wyjaśnienia sytuacji w RFN. Przyczyn wybuchu przemocy poszukiwano w podziałach $\mathrm{w}$ zachodnioniemieckim społeczeństwie, spowodowanych między innymi sporami wokół narodowosocjalistycznej przeszłości. Wskazywano na szybkie przemiany społeczne i pokoleniowe, $\mathrm{w}$ tym niezwykle gorące reakcje niemieckiej młodzieży na wydarzenia międzynarodowe, co dało o sobie znać już w końcu lat 60. Zdarzały się jednak i upraszczające analizy, w których RFN przedstawiano wprost jako zbudowane na nazistowskim fundamencie państwo policyjne, genetycznie wrogo nastawione wobec wszelkiej lewicy, co musiało wywołać zbrojną reakcję ${ }^{62}$. Tego typu głosy były jednak odosobnione.

Wydarzeniom „Niemieckiej Jesieni” z 1977 r. poświęcili osobną książkę - 50 dni grozy - korespondenci w Republice Federalnej - Janusz Moszczeński i Maria Wągrowska. „Polityka” obszernie streszczała także głosy pochodzące z prasy zagranicznej ${ }^{63}$. Oprócz ideologicznego wstępu, w którym autorzy pisali między innymi, że „Prawica wykorzystywała [akty terroru] do zaciekłych ataków na siły postępowe i demokratyczne i ich instytucje, podjęła próbę ograniczenia demokratycznych swobód obywatelskich i wprowadzenia swojego rodzaju ustaw wyjątkowych" ${ }^{64}$, a rządzący RFN socjaldemokrata Helmut Schmidt określany był mianem „reńskiego reakcjonisty", książka była rzetelnym, reporterskim streszczeniem tego, co działo się w zachodnich Niemczech w okresie największego powojennego kryzysu państwa. Oferowała czytelnikom dokładny opis wydarzeń - od porwania Hannsa Martina Schleyera, przez uprowadzenie samolotu Lufthansy, akcję jego odbicia w Mogadiszu, aż po zbiorowe samobójstwo liderów RAF w więzieniu w Stuttgarcie. W książkach i prasowych artykułach niezwykle skrupulatnie odtwarzano konteksty porwania Schleyera - w tym między innymi spory pomiędzy kierowanym przez niego zrzeszeniem przemysłowców a związkami zawodowymi ${ }^{65}$.

Kraje komunistyczne przyjmowały wobec zachodnioniemieckiego terroryzmu różne postawy. Służby specjalne Niemieckiej Republiki Demokratycznej wspierały

\footnotetext{
${ }^{60}$ A. Krzemiński, Wojna sześciu, „Polityka” 1972, nr 18, s. 1, 9.

${ }^{61}$ E. Dylawerski, Pirotechnicy, „Kultura” 1972, nr 27, s. 6-7.

62 A. Bernard, op. cit., s. 101-109.

${ }^{63}$ H. Zdanowski, Dlaczego właśnie w RFN?, „Polityka” 1977, nr 46, s. 10.

${ }^{64}$ J. Moszczeński, M. Wągrowska, op. cit., s. 6.

65 J. Maziarski, Nieudana ofensywa, „Polityka” 1977, nr 51, s. 12.
} 
RAF, dostarczając między innymi sfałszowanych dokumentów i broni ${ }^{66}$. Mordercy Hannsa Martina Schleyera ukrywali się przez pewien czas na terytorium Bułgarii i Jugosławii, lecz informacje o miejscu ich pobytu władze tych krajów przekazały Federalnej Policji Kryminalnej RFN ${ }^{67}$. Kilku członków organizacji przebywało na terytorium PRL, lecz najprawdopodobniej działo się to bez wiedzy i zgody tajnych służb. Dokumenty, zarówno pochodzące z archiwów wywiadu cywilnego, jak i wojskowego, pokazują, że z polskiej perspektywy nie było mowy o współpracy z Frakcją Czerwonej Armii ${ }^{68}$.

W źródłach otwartych terroryści przedstawiani byli bez cienia sympatii dla ich antykapitalistycznego i antykolonialnego programu. Nazywani byli „fanatykami”, „pseudo-rewolucjonistami”, „lewakami”, ich akcje określano jako „szalone”. Opisywano ich jako dzieci z dobrych rodzin, które do brutalnej działalności zaprowadziła nuda, a nie rzeczywiste problemy społeczne. Zachodnioniemieckie realia wymagały radykalnej reformy - przekonywano - lecz w przypadku, gdy wprost nawołuje się do stosowania przemocy, a następnie się ją stosuje, wszelka debata polityczna $\mathrm{z}$ terrorystami przestaje być celowa ${ }^{69}$.

Niektórych opisów trudno nie skojarzyć z obrazem „bananowej młodzieży” z marca 1968 r. - żyjących w luksusie młodych ludzi, czerpiących poczucie bezkarności z wysokiej pozycji społecznej rodziców, realizujących się w pustym radykalizmie. Skojarzenie to nasuwa się jeszcze wyraźniej, gdy przeczyta się, w jaki sposób Zbigniew Domarańczyk opisywał najgłośniejszego międzynarodowego terrorystę lat 70. - Ilicha Ramíreza Sáncheza, znanego jako Carlos lub Szakal, posiadającego autentycznie uprzywilejowane pochodzenie ${ }^{70}$. W streszczonym w „Polityce” wywiadzie, którego Edward Gierek w 1978 r. udzielił jugosłowiańskiemu tygodnikowi „NIN”, pierwszy sekretarz KC PZPR także zauważał, że znacząca część zachodnich terrorystów wywodziła się z „rodzin burżuazyjnych”, co świadczył miało o "klasowym” i "politycznym” charakterze ich działań ${ }^{71}$.

W opisie porwania, a następnie uwolnienia samolotu „Landshut” na pierwszy planie widoczne było współczucie i poczucie solidarności, można powiedzieć - ponad geopolitycznymi podziałami. Zarazem silnie obecny był podziw

\footnotetext{
${ }^{66}$ J. Bauszus, Die RAF-Stasi-Connection, „Focus” 8 V 2007, http://www.focus.de/politik/deutschland/raf/tid-5678/terrorismus_aid_55571.html (dostęp: 26 V 2016).

67 A. Kleikamp, Warum Bulgariens Stasi Linksterroristen abschob, „Die Welt” 9 VIII 2015, http://www.welt.de/geschichte/article144944627/Warum-Bulgariens-Stasi-Linksterroristen-abschob.html (dostęp: 26 V 2016).

68 P. Gasztold-Seń, Der Sicherheitsapparat der Volksrepublik Polen und die Rote Armee Fraktion, „Inter Finitimos” 2011, nr 9, s. 146, 150.

69 J. Moszczeński, M. Wągrowska, op. cit., s. 20, 26, 122, 176-179.

70 Z. Domarańczyk, Terroryzm..., s. 288-306.

71 „Polityka” 1978, nr 22, s. 12.
} 
dla skuteczności antyterrorystycznej jednostki GSG 9, która doprowadziła do uwolnienia przetrzymywanych $\mathrm{w}$ samolocie zakładników ${ }^{72}$.

W zachodniej opinii publicznej największe kontrowersje budziło zbiorowe samobójstwo popełnione przez liderów Frakcji Czerwonej Armii 18 października 1977 r. Kilkuletni pobyt członków grupy w stuttgarckim więzieniu opisywany był przez część prasy jako sposób na ich złamanie. W 1974 r. Andreasa Baadera odwiedził Jean-Paul Sartre, który opowiadał później o strasznych warunkach panujących w zakładzie karnym. Todesnacht von Stammheim z 17 na 18 października dało pożywkę dla dalszych spekulacji i teorii spiskowych. Wiara w to, że Andreas Baader, Gudrun Ensslin i Jan-Carl Raspe zostali zamordowani przez władze RFN łączyć będzie przez następne lata radykałów na całym świecie w nienawiści do zachodniego świata ${ }^{73}$. Paradoksalnie PRL-owscy dziennikarze wykazywali tu więcej zdrowego rozsądku niż ich koledzy na Zachodzie. W chłodnym opisie Moszczeński i Wągrowska obalali głoszone przez adwokatów terrorystów mity na temat nieludzkiego traktowania więźniów w Stammheim i rozwiewali wątpliwości co do popełnionych przez terrorystów samobójstw.

Zastanawiając się nad konsekwencjami działalności terrorystycznej w RFN, relacjonowano debaty toczące się wokół reakcji państwa. Podkreślano, że zarówno rządząca Socjaldemokratyczna Partia Niemiec (SPD), jak i znajdujący się w opozycji chadecy umieli dojść do porozumienia i wspólnie wystąpili przeciwko zagrożeniu ${ }^{74}$. W PRL, podobnie zresztą jak w wielu krajach zachodnich, rytualnie krytykowano wymierzone w terrorystów specjalne, ograniczające prawa obywatelskie przepisy. Nie zadawano sobie jednak pytania, jakie inne wyjście miały władze RFN. Hanna Hartwig twierdziła, że jedynymi efektami działalności RAF w Niemczech było zwiększenie roli służb specjalnych i policji oraz ograniczenie praw obywatelskich ${ }^{75}$.

W 1972 r. głośno dyskutowany był administracyjny środek zakazu wykonywania zawodu (Berufsverbot), fatalnie kojarzący się z czasami narodowosocjalistycznej dyktatury. Przepisy wymierzone były przede wszystkim w adwokatów współpracujących z terrorystami, takich jak Horst Mahler czy Klaus Croissant, któremu w 1979 r. odebrano prawo do wykonywania zawodu. W umiarkowany, wywarzony sposób opisywano toczoną w Niemczech debatę wokół wpływowych w społeczeństwie „sympatyków RAF”. Szybko przetłumaczono i wydano w Polsce powieść oskarżanego o sprzyjanie terrorystom Heinricha Bölla Utracona cześć Katarzyny Blum, będącą głosem w dyskusji ${ }^{76}$. Krytykowano tworzoną przez

\footnotetext{
72 J. Moszczeński, M. Wągrowska, op. cit., s. 80-81, 90.

${ }^{73}$ P. Terhoeven, op. cit.; M. Burleigh, Blood and Rage. A Cultural History of Terrorism, London 2008, s. 244-257.

74 J. Moszczeński, M. Wągrowska, op. cit., s. 104, 117, 34-35, 119.

${ }^{75}$ H. Hartwig, op. cit., s. 18.

${ }^{76}$ H. Böll, Utracona cześć Katarzyny Blum albo jak powstaje przemoc i do czego może doprowadzić, przeł. T. Jętkiewicz, Warszawa 1976.
} 
media atmosferę nagonki. „[...] każdy, stojący na lewo od pewnego schematu czy wyobrażenia o kształcie rzeczywistości zachodnioniemieckiej może być bardzo łatwo pomówiony o sprzyjanie terrorystycznemu podziemiu. Bardzo wiele pisze się w RFN i za granicą o jak najbardziej uzasadnionej obawie utożsamiania radykalizmu społecznego z popieraniem ruchu terrorystycznego. Objawia się to w Republice Federalnej w dwojaki sposób: stopniowym ograniczeniem swobód obywatelskich, co jest rzecz jasna na rękę kołom prawicowo-konserwatywnym oraz przysłowiową "nagonką na czarownice»" - pisali Moszczeński i Wągrowska ${ }^{77}$. Zdawano sobie jednak sprawę, że funkcjonująca bez ograniczeń grupa otwartych wrogów państwa jest na dłużą metę niezwykle niebezpieczna.

Polska opinia publiczna przekonana była o niezwykłej skuteczności zachodnioniemieckiego państwa, które w najbardziej skrajnych interpretacjach skrycie rządzone było przez byłych nazistów, funkcjonariuszy tajnych służb i przemysłowców. Przykład walki z RAF pokazywał jednak, jak niełatwa w zdecentralizowanym i federalnym systemie zachodnioniemieckim była współpraca pomiędzy poszczególnymi ogniwami administracji i policji ${ }^{78}$. Temat wymaga z pewnością dalszych badań, lecz na podstawie przywołanych przeze mnie źródeł można mówić o poczuciu solidarności z państwem zachodnioniemieckim, walczącym z nieznanym i nietypowym zagrożeniem. Solidarność ta opierała się na racjach moralnych (sprzeciw wobec programu i metod RAF) i politycznych (obrona ładu i bezpieczeństwa obywateli, walka z przestępczością). W latach 70 . wyciszone zostały najbardziej agresywne elementy antyniemieckiej retoryki propagandy PRL-u, tak obecne w dekadzie poprzedniej. Odbiór ataków ze strony Frakcji Czerwonej Armii mógł być jedną z tego przyczyn ${ }^{79}$.

We Włoszech atakami terrorystycznymi posługiwały się skrajnie lewicowe oraz postfaszystowskie organizacje zbrojne. W 1970 r. w Mediolanie działalność rozpoczęły Czerwone Brygady, najbardziej znane włoskie ugrupowanie terrorystyczne. Do 1974 r. Brygady skupiały się na podpalaniu samochodów należących do przemysłowców i porwaniach, ale nie posuwały się do mordów. Od 1974 r. organizacja rozpoczęly otwartą wojnę z państwem, w której stosowała zamachy na polityków i prokuratorów. Za kres jej działalności uznaje się rok $1984 \mathrm{r}^{80}$

16 marca 1978 r. doszło w Rzymie do porwania byłego premiera Aldo Moro. Dwunastoosobowe komando w biały dzień zamordowało pięciu członków jego ochrony. Były premier przetrzymywany był przez prawie dwa miesiące, a warunkiem jego uwolnienia było zwolnienie $\mathrm{z}$ więzień kilkunastu bojowników organizacji. Ciało zamordowanego polityka znaleziono w bagażniku samochodu we włoskiej stolicy

77 J. Moszczeński, M. Wągrowska, op. cit., s. 119.

${ }^{78}$ Ibidem, s. 119, 16.

79 J. Szymoniczek, Republika Federalna Niemiec - negatywny bohater PRL, „Rocznik Polsko-Niemiecki” 2012, nr 20.

80 The Terrorism Reader..., s. 27-28, 214-231. 
9 maja $1978 \mathrm{r} .{ }^{81}$ W polskich publikacjach i artykułach prasowych sprawa Aldo Moro była silnie obecna, drobiazgowo odtwarzano społeczno-polityczne kulisy zdarzenia.

Jak wskazywałem wyżej, w przypadku relacji z Niemiec Zachodnich opisy były niezwykle wyważone i ostrożne, rzadko ferowano daleko idące sądy. Portret terroryzmu włoskiego wyglądał zgoła inaczej. Co i rusz pojawiały się wątpliwości, czy faktycznie to skrajnie lewicowe Czerwone Brygady porwały byłego premiera Aldo Moro, czy może stał za tym ktoś inny. „Przebieg turyńskiego procesu wykazał [...], że akty przemocy w swej ogromnej większości inspirowane są przez neofaszystowską prawicę, dążącą do wymierzenie ciosu prawdziwej lewicy włoskiej”"82 - twierdził Domarańczyk. Jak to jednak najczęściej bywa w przypadku dochodzenia „prawdziwych inspiratorów” zdarzeń, autor nie był w stanie przedstawić żadnych argumentów za swoją hipotezą.

W przypadku Włoch często powoływano się na obecność ugrupowań zbrojnych proweniencji faszystowskiej, które samą swoją obecnością prowokowały działania innych grup radykalnych ${ }^{83}$. Często bez wystarczających podstaw twierdzono, że to wspierane przez włoskie służby specjalne faszystowskie bojówki rozpoczęły pełne przemocy „lata ołowiu”, na które lewica jedynie odpowiedziała ${ }^{84}$. Nie wystrzegano się teorii spiskowych. O ile w przypadku Frakcji Czerwonej Armii zwracano uwagę, że jej akcje pośrednio umacniają militaryzację polityki wewnętrznej RFN, a atmosfera zagrożenia w dłuższej perspektywie jest korzystna dla prawicy, o tyle w przypadku włoskich Czerwonych Brygad sądy takie szły o wiele dalej. Andrzej Bernard wprost twierdził, że Brigate Rosse były bezpośrednio sterowane przez włoski wywiad wojskowy, w celu ,usprawiedliwienia zamachów faszystowskich"85. Na temat spisku służb specjalnych, które używały Czerwonych Brygad jako powolnego sobie narzędzia pisali także Dominik Horodyński i Andrzej Bińkowski w „Kulturze” ${ }^{86}$. Dodać należy, że jedynie powtarzali w ten sposób głosy prasy europejskiej, która o kontrolę nad Czerwonymi Brygadami (oprócz służb specjalnych) podejrzewała lożę masońską P2 (Propaganda Due) czy sycylijską mafię ${ }^{87}$. Kiedy nie odbierano Czerwonym Brygadom autentyczności, charakteryzowano jej liderów podobnie jak terrorystów z RAF, czyli jako wyrządzających światowej lewicy wielkie szkody uzurpatorów, podszywających się pod interesy klasy robotniczej ${ }^{88}$.

\footnotetext{
81 Transnational Terrorism..., s. 780.

82 Z. Domarańczyk, Terroryzm..., s. 190.

83 J. Marciniak, op. cit., s. 138-154.

${ }^{84}$ H. Hartwig, op. cit., s. 201-230.

85 A. Bernard, op. cit., s. 144.

86 D. Horodyński, Akta sprawy: Feltrinelli, „Kultura” 1972, nr 13, s. 1, 8; A. Bińkowski, Valpreda, „Kultura” 1972, nr 30, 31, s. 7, 8.

${ }^{87}$ M. Burleigh, op. cit., s. 220.

88 J. Ambroziewicz, Aldo Moro i „Czerwone Brygady”, „Kultura” 1978, nr 13, s. 2, 15.
} 
Fenomenem Dalekiego Wschodu była Japońska Armia Czerwona, która w latach 70. organizowała krwawe ataki i porwania samolotów oraz współpracowała z międzynarodowymi terrorystami różnych ideowych odcieni ${ }^{89}$. Niezwykle silnie opowiadała się za palestyńskimi dążeniami do niepodległości, była bojowo „antysyjonistyczna”, a ideologicznie bliska maoistowskim Chinom ${ }^{90}$. Według polskich autorów żadne wewnętrzne czy międzynarodowe konteksty nie mogły tłumaczyć ich okrutnych akcji ${ }^{91}$. Większość opisów koncentrowała się na tragedii z 30 maja 1972 r., kiedy to japońska bojówka otworzyła ogień na telawiwskim lotnisku Lod, zabijając 26 osób $^{92}$.

W Stanach Zjednoczonych także najbardziej aktywne były grupy rewolucyjnej lewicy, w tym radykalne grupy czarnoskórych mieszkańców USA. Antykapitalistyczną działalność zbrojną prowadziła też organizacja The Weathermen (The Weather Underground) ${ }^{93}$. W 1974 r. opinia publiczna poruszona została historią porwania Patty Hearst. 5 lutego dziewiętnastoletnia prawnuczka miliardera i magnata medialnego Randolpha Hearsta zabrana została ze swojego domu w Berkeley w Kalifornii przez czteroosobowy oddział Symbionicznej Armii Wyzwolenia (SLA) - radykalnej grupy w typie RAF, dokonującej napadów i morderstw na terenie zachodniego wybrzeża USA. Szczegóły sprawy do dziś podawane są w wątpliwość, lecz faktem pozostaje, że po okresie przebywania w niewoli, poddana silnej presji ze strony porywaczy, Pattty zaczęła utożsamiać się z ideologią SLA i uczestniczyć w akcjach grupy. Większość jej członków została zabita podczas strzelaniny z policją w Los Angeles w maju 1974 r. Patty schwytano ponad rok później, a jej proces zakończył się marcu 1976 r. ${ }^{94}$ Dla polskiego czytelnika sprawę porwania opisał Jerzy Bukowski. Książka, choć utrzymana w tonie sensacyjnym - opublikowana w serii Krajowej Agencji Wydawniczej „Zdarzenia sensacje, zagadki" - w sposób rzeczowy opisywała odtworzone na podstawie amerykańskiej prasy fakty. Bukowski barwie opisał transformację Patty z ofiary we wspólniczkę terrorystów, jej proces i reakcje społeczne.

W sferze analitycznej historia porwania, przestępczej działalności i procesu Patty Hearst była przede wszystkim opowieścią o społecznych i politycznych napięciach w USA. W wizji Bukowskiego był to kraj powszechnej przemocy i poszukujących sensacji mediów, a dla mieszkających poza enklawami luksusu zwykłych ludzi - niezwykle niebezpieczny. O panujących w Stanach Zjednoczonych nierównościach społecznych świadczyć miało jedno z żądań SLA: przeznaczanie przez rodzinę Hearstów czterystu milionów dolarów na bony żywnościowe

\footnotetext{
89 The Terrorism Reader..., s. 30.

90 J. Marciniak, op. cit., s. 122-137.

91 H. Hartwig, op. cit., s. 111-122.

92 Z. Domarańczyk, Terroryzm..., s. 74-77.

93 J. Tyszkiewicz, E. Czapiewski, op. cit., s. 958.

94 Transnational Terrorism..., s. 435.
} 
dla najbardziej potrzebujących mieszkańców Kalifornii. Bukowski pisał o funkcjonującej na marginesie życia społecznego "drugiej Ameryce” - podziemnym społeczeństwie „wolnych elektronów”: uciekinierów, przestępców i terrorystów, których liczbę za zachodnią prasą szacował na 80 tys. osób ${ }^{95}$. Sprawa Patricii Hearst była dowodem na „nie rozwiązane problemy społeczeństwa amerykańskiego oraz jego agend publicznego bezpieczeństwa" ${ }^{\text {" }}$.

Rysując generalną linię partii komunistycznych wobec terroryzmu skrajnej lewicy, Szmidt twierdził, że o ile aktywiści tych organizacji są z perspektywy Moskwy straceni, o tyle należy z życzliwością odnosić się do rzesz ich sympatyków na Zachodzie. Jako że cechuje ich antykapitalistyczna i antykolonialna emocja, mogą zostać skierowani na „właściwą drogę” - czyli poparcie dla lokalnych partii komunistycznych i globalnej polityki Związku Radzieckiego ${ }^{97}$.

\section{Bliski Wschód}

Terroryzm bliskowschodni narodził się ze zbrojnego oporu przeciwko żydowskiemu osadnictwu w Palestynie. Bezpośrednich przyczyn badacze doszukują się $\mathrm{w}$ reakcjach na wynikające $\mathrm{z}$ wojny sześciodniowej zdobycze terytorialne Izraela z roku 1967. Wtedy to powstała w maju 1964 r. Organizacja Wyzwolenia Palestyny ${ }^{98}$ zadecydowała o planowym używaniu metod terrorystycznych do osiągnięcia swojego celu - palestyńskiej suwerenności państwowej. Palestyńczycy, pomimo używanych przez nich metod, liczyć mogli na poparcie i sympatię świata arabskiego, ZSRR oraz niektórych środowisk na Zachodzie ${ }^{99}$.

Przez lata dla komunistycznej propagandy wystąpienia palestyńskich fedainów były uzasadnioną odpowiedzią na agresywny żydowski nacjonalizm, roszczący sobie prawa do arabskich ziem na Bliskim Wschodzie. Co ciekawe, temat syjonizmu przy opisie bliskowschodniego terroryzmu w latach 70. pojawił się tylko w pracy Jerzego Marciniaka, który mocno eksploatował ten wątek ${ }^{100}$.

Zwracano uwagę, że społeczność ta w doborze metod i celów swojej działalności była bardzo podzielna. Jasir Arafat, abstrahując od jego zmieniającego się stanowiska w tej sprawie, prezentowany był powszechnie jako adwokat rozwiązania zakładającego współistnienie izraelskiej i palestyńskiej państwowości.

95 J. Bukowski, op. cit., s. 15, 20, 59.

${ }^{96}$ Ibidem, s. 107.

97 T.L. Szmidt, op. cit., s. 330-331.

98 H. Cobban, The Palestinian Liberation Organization. People, Power and Politics, Cambridge 1984, s. $28-30$.

99 The Terrorism Reader..., s. 30-31; J. Tyszkiewicz, E. Czapiewski, op. cit., s. 707-709.

100 J. Marciniak, op. cit., s. 91; o „syjonistycznym terroryzmie” pisał też Jerzy Genello: Recenzja: Les Palestiniens. Collection Bordas Série Connaissance - Information, Paris 1972, „Sprawy Międzynarodowe" 1973, nr 10, s. 144-146. 
Podkreślano, że chociaż prowadzi wojnę partyzancką na spornych terytoriach, nie ucieka się do aktów indywidualnego terroru i nie przenosi wojny z Izraelem poza Bliski Wschód. Aktywność konkurencyjnego wobec Arafata Ludowego Frontu Wyzwolenia Palestyny (LFWP), jawnie głoszącego chęć likwidacji żydowskiego państwa, oceniana była negatywnie ${ }^{101}$ Lider LFWP George Habasz przedstawiany był jako rozbijający jedność Palestyńczyków radykał, izolowany dodatkowo we własnej społeczności ${ }^{102}$.

Na podstawie pochodzących z lat 70. lektur można stwierdzić, że warunkowo akceptowane były ataki, których grupy palestyńskie dokonywały na terenach spornych z Izraelem, potępiane natomiast akty przemocy, które dotykały interesów lub obywateli izraelskich poza granicami Bliskiego Wschodu.

I tak na przykład atak bombowy na brytyjski konsulat w Jerozolimie w marcu 1969 r. oznaczał - według Jerzego Marciniaka „zdemaskowanie izraelsko-brytyjskiej transakcji"103 - polegającą na zakupie czołgów, używanych później do walki $\mathrm{z}$ arabskimi sąsiadami. Jako usprawiedliwione przedstawione zostało nawet porwanie samolotu belgijskich linii lotniczych Sabena, którego w maju $1972 \mathrm{r}$. na trasie Wiedeń-Tel Awiw dokonało komando Czarnego Września ${ }^{104}$. W akcji odbicia samolotu dwoje zamachowców zostało zastrzelonych, dwoje pozostałych izraelski sąd skazał na dożywocie. „Militarystyczny rząd państwa Izrael odniósł «zwycięstwo» nad grupką palestyńskiej młodzieży, której patriotyzm nakazał odrzucić nadmierne wyczekiwanie na wolność, która przecież sama nigdy nie przychodzi” 105 - komentował pokłosie porwania Marciniak.

Psychologicznym przełomem było porwanie i zamordowanie izraelskich olimpijczyków w Monachium. 5 września 1972 r. ośmiu terrorystów wdarło się do wioski olimpijskiej, zabiło dwóch izraelskich sportowców i wzięło dziewięciu zakładników. Zamachowcy żądali uwolnienia ponad dwustu przetrzymywanych w więzieniach na całym świecie terrorystów, w tym członków RAF i Japońskiej Czerwonej Armii. W toku negocjacji porywacze wraz z zakładnikami zostali przewiezieni na wojskowe lotnisko Fürstenfeldbruck pod Monachium. Próba odbicia przetrzymywanych sportowców zakończyła się strzelaniną, w wyniku której zabici zostali wszyscy żydowscy zakładnicy ${ }^{106}$.

6 września, czyli na dzień po zamachu, Wydział Propagandy, Prasy i Wydawnictw KC postulował nałożenie ograniczeń na informacje o zamachu, który w złym świetle stawiał palestyńskie starania niepodległościowe. „Należy - jak

101 J. Marciniak, op. cit., s. 100, 102; T. Pasierbiński, Kwestia palestyńska, „Polityka” 1978, nr 22, s. 2.

102 Terrror, „Polityka” 1972, nr 38, s. 4-5; W. Osiatyński, Rozpacz i terror, „Kultura” 1972, nr 40, s. $1,4-7$.

103 J. Marciniak, op. cit., s. 106.

104 Transnational Terrorism..., s. 313-314.

105 J. Marciniak, op. cit., s. 121-122.

106 Transnational Terrorism..., s. 338-343. 
pisano - przeciwdziałać wytworzeniu się szerokiej kampanii prasowej w związku z wypadkami w Monachium", m.in. poprzez niepublikowanie wypowiedzi olimpijczyków ${ }^{107}$. Nie można jednak powiedzieć, aby udało się to osiągnąć. Duże wojewódzkie dzienniki partyjne („Dziennik Bałtycki”, „Trybuna Robotnicza”) wydrukowały jedynie depesze PAP- $\mathrm{u}^{108}$. Rozbudowane, ciągnące się przez kilka numerów reporterskie relacje pojawiły się w „Polityce” i „Kulturze”, których dziennikarze (Daniel Passent i Maciej Wierzyński) znajdowali się na miejscu ${ }^{109}$. W związku z monachijską tragedią „Polityka” uczyniła światowy terroryzm głównym tematem swojego następnego wydania. Pod wspólnym pytaniem „Czy terror zagraża światu?” komentarze zamieścili czołowi autorzy „Polityki”: Mirosław Ikonowicz, Adam Krzemiński, Tadeusz Pasierbiński, Marian Turski, Jerzy Urban i Henryk Zdanowski. W serii artykułów scharakteryzowali większość występujących wtedy na świecie grup terrorystycznych ${ }^{110}$. Zamach w Monachium był też szeroko dyskutowany w wydawnictwach książkowych.

Za zachodnią prasą kwestionowano autentyczność Czarnego Września. Odpowiedzialna za zamach na olimpijczyków w Monachium organizacja wprost przedstawiana była jako zinfiltrowana i kierowana przez izraelski wywiad ${ }^{111}$. W sposób pełny hipotezę tę rozwinął Zbigniew Domarańczyk. Wszystko wskazywało na to - przekonywał - że Czarny Wrzesień w 1972 r. działał na zlecenie tajnych służb Izraela. Ataki w niepokojący sposób zbiegały się z zaplanowanymi operacjami państwa żydowskiego na Bliskim Wschodzie. „Takich «zbiegów okoliczności» można by przytoczyć dużo więcej. Niejako prawidłowością staje się fakt, że za każdym razem, gdy Izrael dopuszcza się kolejnego aktu agresji przeciwko arabskim sąsiadom, aktu budzącego powszechne potępienie, albo kiedy zarysowuje się możliwość poprawy stosunków między Palestyńskim Ruchem Oporu a przywódcami niektórych państw na Bliskim Wschodzie, ekstremistyczne ugrupowania podejmują bezmyślne i okrutne akcje terrorystyczne, odwracające uwagę światowej opinii publicznej i dyskredytujące słuszną walkę narodu palestyńskiego"112. Działalność terrorystycznej bojówki to po prostu „sabotaż” - podsumowywał Domarańczyk.

107 T. Leszkowicz, Polityka prasowa ..., s. 114-115.

108 XX Igrzyska Olimpijskie zawieszone. Zamach komandosów palestyńskich, „Dziennik Bałtycki” 6 IX 1972; Polska opinia społeczna potępia zamach terrorystów. Dramatyczna sytuacja na Olimpiadzie, „Trybuna Robotnicza” 6 IX 1972; Wielka tragedia w Monachium. Wydarzenia na lotnisku Fuerstenfeldbruck, „Dziennik Bałtycki” 7 IX 1972; Igrzyska XX Olimpiady - wznowione, „Trybuna Robotnicza” 7 IX 1972.

109 D. Passent, Czarny Wrzesień w Monachium, „Polityka” 1972, nr 37; M. Wierzyński, Monachium godzina 5.20, „Kultura” 1982, nr 38, s. 1, 8.

110 Terrror, „Polityka” 1972, nr 38, s. 1, 3, 4-5.

111 A. Bernard, op. cit., s. 170.

112 Z. Domarańczyk, Terroryzm, Warszawa 1979, s. 71. 


\section{Ameryka Południowa i Środkowa}

Pomimo znacznej odległości geograficznej w polskich publikacjach opisywane były także ataki terrorystyczne mające miejsce w Ameryce Południowej i Środkowej. W latach 60. i 70. polscy reporterzy i dziennikarze relacjonowali konflikty zbrojne w najdalszych częściach świata. Postaci takie, jak Ryszard Kapuściński, przekazywały czytelnikom fascynację socjalistycznymi przemianami w Ameryce Łacińskiej, czy to wprowadzanymi metodami zbrojnymi (Ernesto Che Guevara), czy też demokratycznymi (Salvador Allende) ${ }^{113}$.

Gdy chodziło o postkolonialne kraje Ameryki Łacińskiej, to - zgodnie z klasyfikacją Longina Tadeusza Szmidta - używanie przemocy prezentowane było generalnie jako zasadna reakcja na politykę wojskowych dyktatur ${ }^{114}$. Kontrowersje pojawiały się przy akceptacji dla metod typowo terrorystycznych: powodowania ofiar wśród ludzi niezwiązanych z wojującymi stronami, napadów na banki, porwań, stosowania odpowiedzialności zbiorowej. Andrzej Bernard pytał, jak oceniać sytuację, gdy grupa bojowników dokonuje krwawego ataku na więzienie, w którym przetrzymywani i torturowani przez tajną policję są współtowarzysze broni? ${ }^{115}$ Także Hanna Hartwig twierdziła, że przemoc okazywała się jedyną metodą politycznej walki w Ameryce Łacińskiej, a zmiana systemu politycznego i społecznego dokonać się tam może tylko w wyniku gwałtownego przewrotu ${ }^{116}$. Obecność zbrojnych organizacji spod różnych ideowych znaków oraz stosujących równie brutalne metody struktur państwa tworzyła obraz „wojny wszystkich ze wszystkimi”, w której nie obowiązywały żadne reguły uczciwej walki. Przemoc stosowali wszyscy, trudno było więc wytyczyć wyraźne granice między tym, co określić można było mianem terroryzmu, a co nie ${ }^{117}$.

W Urugwaju od lat 60. działała radykalna lewicowa organizacja Tupamaros. Specjalizowała się $\mathrm{w}$ napadach na banki i porwaniach, rzadko posługując się morderstwami. Ryszard Kapuściński w depeszach z końca lat 60. podkreślał, że unikała najbrutalniejszej przemocy i nazywał ją „sumieniem ludu”"118. Do końca lat 70. organizacja została rozbita, a jej działalność spowodowała zaostrzenie państwowych represji wobec przeciwników politycznych ${ }^{119}$.

Urugwajskich terrorystów-partyzantów opisał Jerzy Marciniak w książce Uwaga, komunikat nadzwyczajny. Relacjonując porwania dyplomatów i agentów

113 A. Domosławski, Kapuściński non-fiction, Warszawa 2010, s. 265.

114 Terror, „Polityka” 1972, nr 38, s. 4-5.

115 A. Bernard, op. cit., s. 48-61.

116 H. Hartwig, op. cit., s. 21-40.

117 J. Marciniak, op. cit., s. 72-83.

118 A. Domosławski, op. cit., s. 239, 263.

119 W. Rómmel, Recenja: „Nous les Tupamaors”, ed. Francois Maspero, Paris 1971; Richard Gott, "Guerilla Movements in Latin America”, Thomas Nelson and Sons, London 1970, „Sprawy Międzynarodowe" 1972, $\mathrm{nr} 7-8$, s. 210-213. 
FBI, dokonywane przez grupę, podkreślał, że tego typu akcje były potępiane przez urugwajską partię komunistyczną. Pomimo braku podporządkowania się lokalnej partii, Tupamaros określani byli w miarę pozytywnie jako „organizacja polityczno-wojskowa wywodząca swój rodowód z postępowych, narodowowyzwoleńczych walk Ameryki Południowej w XIX w." ${ }^{120}$. Także organizowane przez Tupamaros napady na banki okazywały się usprawiedliwione, gdyż zdobyte w ten sposób pieniądze - jak twierdził Marciniak - były w rzeczywistości „wyciśnięt[e] przez wielki business z pracy narodu urugwajskiego" ${ }^{\prime 21}$. Nie można jednak mówić o jednolitej linii wobec urugwajskich bojowców - w 1972 r. dziennikarze „Polityki” twierdzili bowiem, że w niewystarczający sposób korzystali oni z możliwości oferowanych przez system polityczny i zbyt pochopnie sięgnęli po broń ${ }^{122}$.

Inna, głośna i komentowana w Polsce sprawa miała miejsce w Gwatemali. 31 marca 1970 r. uprowadzony został zachodnioniemiecki ambasador Karl von Spreti. Porywacze z lewicowej partyzantki żądali uwolnienia kilkunastu więźniów, a gdy ich warunki nie zostały spełnione, 5 kwietnia zastrzelili dyplomatę ${ }^{123}$. W swoim pisanym z Meksyku reportażu Ryszard Kapuściński wskazywał na brutalność gwatemalskiego reżimu, który powinien znaleźć się w centrum zainteresowania jako właściwa przyczyna porwania. Dowodził, że w przypadku środkowoamerykańskich dyktatur tylko użycie przemocy może okazać się skutecznym sposobem na zmianę tragicznej sytuacji kraju ${ }^{124}$. „W tamtym systemie nie można liczyć na walkę pokojową, na pracę uświadamiającą wśród mas, na agitację, bo nie masz żadnych możliwości - żadnych mechanizmów działania, żadnych szans po latach tłumaczył Kapuściński Arturowi Domosławskiemu. - Jesteś schwytany za gardło i jeśli chcesz być człowiekiem, musisz tylko umrzeć. Więc jakżeż tych ludzi nazywać terrorystami?" 125 .

Za Kapuścińskim wydarzenie to opisywane było więc jako naturalny element brutalnej wojny domowej, w której wszystkie chwyty były dozwolone ${ }^{126}$. Także Zbigniew Domarańczyk twierdził, że śmierć dyplomaty była tylko jednym z wielu epizodów w wieloletniej wojnie domowej w Gwatemali. Bezpośrednią odpowiedzialność za śmierć Spretiego ponosił de facto rząd USA, który - zdaniem autora - miał decydujący głos we wszelkich sprawach wagi państwowej ${ }^{127}$.

Używanie przemocy przeciwko strukturom państwa w „krajach trzeciego świata” otwarcie pochwalał Longin Tadeusz Szmidt. „Stosunek ruchu robotniczego

\footnotetext{
120 J. Marciniak, op. cit., s. 31.

121 Ibidem, s. 32.

122 Terrror, „Polityka” 1972, nr 38, s. 1, 3, 4-5.

123 Transnational Terrorism..., s. 171.

124 R. Kapuściński, Dlaczego zginą Karl von Spreti, Warszawa 1970.

125 A. Domosławski, op. cit., s. 275.

126 J. Marciniak, op. cit., s. 35-59.

127 Z. Domarańczyk, Terroryzm..., s. 80.
} 
do terroryzmu o charakterze postępowym, antyimperialistycznym czy narodowowyzwoleńczym, a taki występuje w państwach rozwijających się, powinien być pozytywny. Wobec braku zorganizowanych masowych ruchów ludowych terroryzm tego rodzaju pobudza masy do wystąpień politycznych o charakterze żywiołowym"128 - twierdził.

Wokół używania przemocy w imię racji politycznych toczyły się w Polsce żywe debaty ${ }^{129}$. Już książka Kapuścińskiego o porwaniu i zabójstwie ambasadora Spretiego wywołała polemiki. Wiktor Osiatyński zarzucał reporterowi, iż ten usprawiedliwia morderstwo ${ }^{130}$. Moralnej oceny użycia przemocy dotyczyła też na przykład polemika w „Polityce” z 1977 r. Wojciech Giełżyński dowodził, że wymaganie od uczestników antyrządowych partyzantek latynoamerykańskich zachowywania powszechnie uznanych metod walki i nieużywania metod terrorystycznych (zamachów, napadów na banki, porwań) musiało być równoznaczne ze skazaniem ich na porażkę ${ }^{131}$. Z Giełżyńskim polemizował Czesław Czapów. Tenże - socjolog, więziony w okresie stalinowskim żołnierz AK - powołując się na swoje okupacyjne doświadczenia, wspominał, że nawet w odpowiedzi na hitlerowski terror członkowie polskiego ruchu oporu nie posługiwali się porwaniami, odpowiedzialnością zbiorową czy mordowaniem rodzin niemieckich oficerów. Metody w oczywisty sposób niemoralne nigdy nie są jedynymi drogami prowadzącymi do osiągnięcia politycznych celów - argumentował ${ }^{132}$. W odpowiedzi Giełżyński odpowiadał, że w krajach rządzonych despotycznie, w sytuacji braku możliwości oddziaływania na sferę publiczną metodami pokojowymi, używanie metod terrorystycznych nie może zostać uznane za niemoralne ${ }^{133}$.

\section{Wnioski}

Analiza wybranych przeze mnie źródeł pozwala na wyciągnięcie kilku wniosków.

Po pierwsze, zaskakuje względnie pełny, opisowy i aideologiczny - w stosunku do oczekiwań i potocznych intuicji - obraz międzynarodowego terroryzmu w latach 70. Większość zawierających propagandowe wtrącenia fragmentów znajdowało się we wstępach lub zakończeniach przywoływanych prac, sprawia też wrażenie dopisanych na wyraźne zalecenie wydawcy lub redaktora. Na tym tle wyróżniał się nieco piszący dla wydawnictwa MON Andrzej Bernard, w którego

\footnotetext{
128 T.L. Szmidt, op. cit., s. 331.

129 W. Borodziej, Vom Warschauer Aufstand zum Runden Tisch. Politik und Gewalt in Polen 1944-1989, w: 1989 und die Rolle der Gewalt, hrsg. M. Sabrow, Göttingen 2012, s. 278-304.

130 A. Domosławski, op. cit., s. 279.

131 W. Giełżyński, Bez psychozy, „Polityka” 1977, nr 44, s. 13.

132 C. Czapów, Skuteczność czy moralność?, „Polityka” 1977, nr 50, s. 11.

133 W. Giełżyński, Polemika czy insynuacja?, „Polityka” 1977, nr 50, s. 13.
} 
książce najwięcej było „prawomyślnych” elementów: konsekwentnego stosowania marksistowskich kategorii, antyamerykanizmu czy „antysyjonizmu”. Na poziomie podstawowych faktów i świadomości skali zjawiska, stan dostępnej wiedzy na temat terroryzmu ocenić należy jako pokaźny.

Autorzy korzystali z zachodnich źródeł, przede wszystkim prasy i literatury naukowej. Oprócz omówionych powyżej zagadnień, z analizowanych przeze mnie źródeł polscy czytelnicy dowiedzieć się mogli także o terroryzmie separatystycznym - w Kraju Basków, Irlandii Północnej ${ }^{134}$, Quebeku ${ }^{135}$, działalności chorwackich ustaszy ${ }^{136}$, a nawet marginalnej grupie Molukańczyków porywających pociągi na terenie Holandii ${ }^{137}$. Można było znaleźć wyczerpujące informacje o porwaniach samolotów ${ }^{138}$, ale i refleksje dotyczące roli kobiet $\mathrm{w}$ ugrupowaniach terrorystycznych ${ }^{139}$.

Stosowana w latach 70. definicja terroryzmu, którą można sformułować na podstawie literatury, pozwalała na ustalenie, kiedy użycie przemocy w polityce uznano za uzasadnione i kiedy można mówić o słusznej walce narodowowyzwoleńczej, a kiedy usprawiedliwione nie było. Czynnikiem decydującym była możliwość lub brak możliwości legalnego wpływu na życie publiczne. Czasem posługiwano się także terminem terroryzmu państwowego - zarezerwowanym dla Stanów Zjednoczonych, Izraela oraz wojskowych dyktatur południowoamerykańskich.

Opisy terroryzmu oczywiście naznaczone były geopolitycznym położeniem Polski, a problem analizowano jako specyficzny dla świata zachodniego i postkolonialnego „trzeciego świata”. Za źródła rozprzestrzeniającej się w świecie politycznej przemocy uznawano kapitalizm i kolonializm, postrzegane jednak często przez pryzmat konkretnych, empirycznych analiz, a nie tylko jako ideologiczne kategorie.

Konteksty występowania terroryzmu w RFN i Włoszech, które do dzisiaj są przedmiotem badań i dyskusji, prezentowane były w większości przypadków

134 A. Bernard, op. cit., s. 76; H. Hartwig, op. cit., s. 41-49, 94-110; S. Klimkiewicz, Nowa faza konfliktu w Irlandii Pótnocnej, „Sprawy Międzynarodowe” 1972, nr 10, s. 56-71; G. Mioduszewska, Recenzja: J. Bowyer Bell, „The Secret Army, The IRA 1916-1970”, P. Coogan, „The IRA”, „Sprawy Międzynarodowe" 1974, nr 4, s. 178-181.

135 J. Jaskiernia, Międzynarodowa aktywność Quebeku a tendencje separatystyczne, „Sprawy Międzynarodowe" 1978, nr 11, s. 126-138.

136 S. Strumiński, Ustasze w Australii, „Polityka” 1972, nr 35, s. 9.

137 H. Hartwig, op. cit., s. 80-93; Z. Domarańczyk, Terrroryzm..., s. 20-42.

138 Z. Domarańczyk, Piractwo XX wieku..., 227-245, 267-279; Z. Galicki, Bezprawne zawładnięcie statkiem powietrznym, „Sprawy Międzynarodowe”, $1971 \mathrm{nr}$ 2; idem, Konwencja o zwalczaniu bezprawnych czynów przeciw bezpieczeństwu lotnictwa cywilnego, „Sprawy Międzynarodowe” 1971, nr 12; L. Łukasik, Prawnomiędzynarodowe środki zwalczania terroryzmu powietrznego, „Sprawy Międzynarodowe" 1973, nr 7-8, s. 120-139; J. Odrobiński, Terroryzm i przestępne uprowadzenie statków powietrznych, „Problemy Kryminalistyki” 1978, nr 131.

139 H. Hartwig, op. cit., s. 231-239. 
uczciwie i rzeczowo. Lewicowy terroryzm w krajach Europy Zachodniej nie mógł liczyć na żadne propagandowe wsparcie. W Polsce w oficjalnym obiegu nie występowali „sympatycy” RAF czy Czerwonych Brygad, co oprócz wielu innych różnic w stosunku do świata zachodniego, spowodowane było odmienną ewolucją ruchu młodzieżowego 1968 r. ${ }^{140}$ Lektura przywołanych przeze mnie tekstów upoważnia do wniosku, że w PRL nie był obecny mit „słusznej walki” lewicowych terrorystów. Przeciwnie, mity te były dekonstruowane. Zauważano, że moda na radykalne ideologie przyciągała do terrorystycznych bojówek zwykłych kryminalistów, powodując trudność w odróżnieniu przemocy politycznej od niepolitycznej ${ }^{141}$.

W sprawach bliskowschodnich Jasir Arafat uznawany był za jedynego prawowitego reprezentanta interesów palestyńskich w świecie. Inne ugrupowania, takie jak Ludowy Front Wyzwolenia Palestyny czy Czarny Wrzesień odrzucano jako rozbijające jedność ruchu, a ich terrorystyczne metody potępiane. Pomimo wyraźnie antyizraelskiego nastawienia autorów analizujących sytuację na Bliskim Wschodzie w sposób jednostronny, przykłady otwartego usprawiedliwiania przemocy były rzadkie.

Stosowanie przemocy przez walczące $\mathrm{z}$ wojskowymi dyktaturami południowoamerykańskie guerille uznawane było za uzasadnione ${ }^{142}$. Jednocześnie toczyły się na ten temat publiczne debaty. W przeciwieństwie do opisów krajów zachodnich, sytuacja w Ameryce Łacińskiej przedstawiana była bardziej schematycznie - przede wszystkim jako pole walki wyzwoleńczej z dyktatorami wspieranymi przez Amerykanów. Ryszard Kapuściński w latach 70. wprost twierdził, że właśnie w taki czarno-biały sposób widział rzeczywistość „trzeciego świata”143. Bojownicy środkowo- i południowoamerykańscy z pewnymi zastrzeżeniami otrzymywali swoistą „licencję na zabijanie”. Można było w ten sposób wysnuć wniosek, że im dalej ktoś znajdował się od Europy (i tym samym od PRL), na więcej mógł sobie pozwolić i zadawano mu mniej pytań, o stosowane w politycznej walce metody.

Temat obrazu terroryzmu w PRL-owskiej „sferze publicznej” wydaje się niezwykle ciekawy, zarówno z perspektywy ogólnej (tu konieczne byłyby całościowe kwerendy prasowe i archiwalne), jak i poszczególnych przypadków, na przykład próby generalnego spojrzenia na odbiór działań Frakcji Czerwonej Armii w Polsce. Połączenie badań nad polityką władz (państwowych, partyjnych, służb specjalnych) wobec terroryzmu $\mathrm{z}$ analizą publicznego obrazu i postaw społecznych wobec niego pozwoli na zrozumienie stosunku PRL do jednego z najważniejszych fenomenów drugiej połowy XX w.

\footnotetext{
140 P. Osęka, My, ludzie z marca. Autoportret Pokolenia '68, Warszawa-Wołowiec 2015.

141 A. Bernard, op. cit., s. 29-30.

142 Ibidem, s. 217.

143 A. Domosławski, op. cit., s. 327.
} 


\section{International terrorism in the Polish literature and press of the 1970s (selected examples) (Abstract)}

In the 1970s in Western Europe, in the United States, in the Middle East and in Central and South America many brutal terrorist attacks took place. The public opinion witnessed the activity of various groups, representing different systems of values. The acts of political violence were exercised in the name of ideology, national liberation or religion. Polish public opinion during the communist rule observed the happenings from a distance, but with much attention. People's Poland in the 1970s published more than a dozen academic, journalist and popular works on the topic of terrorism. The most influential weekly papers (Polityka, Kultura) dedicated many features to the problem of terrorism. The article, basing on books and press articles from the period, aims to answer two questions. What did the state of public knowledge about terrorism, which could be acquired from open sources, look like? How was the phenomenon of international terrorism and its various forms described and evaluated?

\section{Bibliografia (wybór)}

Bernard A., Strategia terroryzmu, Warszawa 1978

Borodziej W., Vom Warschauer Aufstand zum Runden Tisch. Politik und Gewalt in Polen 1944-1989, w: 1989 und die Rolle der Gewalt, hrsg. M. Sabrow, Göttingen 2012

Bukowski J., Patty czy Tania? Historia Patrycji Hearst, Warszawa 1977

Burleigh M., Blood and Rage. A Cultural History of Terrorism, London 2008

Domarańczyk Z., Piractwo XX wieku, Warszawa 1974

Domarańczyk Z., Terroryzm, Warszawa 1979

Domosławski A., Kapuściński non-fiction, Warszawa 2010

Gasztold-Seń P., Der Sicherheitsapparat der Volksrepublik Polen und die Rote Armee Fraktion, „Inter Finitimos" 2011, nr 9

Hartwig H., Zawód: terrorysta, Warszawa 1979

Marciniak J., Uwaga, komunikat nadzwyczajny, Warszawa 1976

Moszczeński J., Wągrowska M., 50 dni grozy, Warszawa 1978

Muszyński J., Utopiści i desperaci - wspótczesna ultralewica, Warszawa 1979

Szmidt L.T., Terroryzm a państwo. Studium poświęcone historycznym, socjologicznym i agonologicznym aspektom terroryzmu, Lubin 1979

Terhoeven P., Deutscher Herbst in Europa. Der Linksterrorismus der Siebziger Jahre als transnationales Phänomen, München 2014

The Terrorism Reader, ed. D.J. Whittaker, London 2003

Transnational Terrorism. A Chronology of Events, 1968-1979, ed. E.F. Mickolous, London 1980

Jakub Szumski, doktorant w Instytucie Historii im. Tadeusza Manteuffla PAN; laureat I narody w konkursie na Debiut Historyczny Roku 2014; interesuje się społeczną i polityczną historią Polski lat siedemdziesiątych i osiemdziesiątych XX w. oraz historią służb specjalnych.

Kontakt: jszumski@ihpan.edu.pl 